\title{
Downgrading among higher education graduates in Italy and France: exploring regional differences
}

\section{La sobreeducación de los graduados universitarios en Italia y Francia: explorando las diferencias regionales}

\author{
Maria Carella ${ }^{1^{*}}$ (iD) \\ Jean-François Léger ${ }^{2}$
}

\begin{abstract}
In France and Italy - like all the countries of the European Union - the proportion of higher education graduates in the working population has continued to increase. At the same time, the number of jobs requiring this level of education has not grown as quickly. In France and Italy, this has meant a decrease in the proportion of tertiary graduates who occupy managerial positions, and a growing share of these graduates hold jobs as middle and low ranking employees.

Several studies have investigated the phenomenon of professional downgrading, focusing on its structural determinants and socio-economic implications at the national level and examining international differences. Nevertheless, only a few studies explore disparities in over-education and compare nations at the regional level.

By addressing the need for a spatial approach to this subject, which is so far lacking in the scientific literature, this paper examines the downgrading of higher education graduates in Italy and France at the regional level and discusses the real occupational returns for high levels of education. Using data from the Italian and French censuses, the findings of this analysis show significant sub-regional heterogeneities regarding access to managerial positions for graduates according to the territorial unit observed.
\end{abstract}

Keywords: over-education; higher education graduates; access to managerial positions; regional inequalities; France; Italy.

\section{Resumen}

En Francia e Italia, como en el resto de los países de la Unión Europea, la proporción de los graduados universitarios sigue aumentando en la población activa. Al mismo tiempo, los trabajos que requieren este nivel educativo no están creciendo tan rápidamente. En Francia e Italia, esto se traduce en una disminución de la proporción de titulados superiores que ocupan cargos directivos, y en un aumento de la proporción de los que ocupan puestos de trabajo como obreros o empleados de categoría media o baja. Varias aportaciones han analizado el fenómeno de la sobreeducación, centrándose en sus determinantes estructurales y en las consecuencias socioeconómicas a nivel de país y examinando también las diferencias entre países. Sin embargo, solo algunos de ellos han intentado explorar las disparidades en la sobreeducación comparando los países a nivel regional. Abordando la necesidad de un enfoque espacial/ territorial de este tema, que hasta ahora falta en la literatura científica, en este artículo se examina la desvalorización de los graduados universitarios en Italia y Francia, a una escala regional, y se examinan los verdaderos beneficios profesionales de la obtención de un título de educación superior. Utilizando datos de los censos italiano y francés, los resultados de este análisis muestran importantes heterogeneidades interregionales en el acceso a puestos directivos para los titulados superiores.

Palabras clave: sobreeducación; graduados universitarios; acceso a puestos directivos; disparidades regionales; Francia; Italia.

1 Department of Political Sciences, University of Bari “Aldo Moro", Bari, Italy. maria.carella1@uniba.it. * Corresponding author

2 Demography Institute (IDUP), University of Paris 1 Pantheon-Sorbonne, Paris, France. jfleger@univ-parisl.fr 


\section{Introduction}

For at least thirty years, in many Western countries, 'the professional integration of young people in access to employment has been characterized by an increasing downgrading' (Chabault, 2008, p. 185). This phenomenon, also known as over-education, refers to individuals whose education exceeds those required for the job they occupy (Green, McIntosh \& Vignoles, 2000; McGuinness, 2006). Long spared from professional downgrading, higher education graduates are increasingly confronted with it, especially since the proportion of young people entering higher education has grown significantly. Indeed, the median value of the percentage of tertiary-level graduates aged 30 to 34 has risen from 22\% in 1993 to 46\% in 2018 in EU-15 area countries (Eurostat, 2019). ${ }^{3}$

In Europe, studies on over-education were more widespread in the 1990s, when a significant increase in the educational level of the population produced an excess in the educated labour supply. Over time the literature on this topic has been significantly enriched (see Chabault, 2008 for a review), and interest in higher education graduates has even been seen in seminal contributions (Gautié \& Nauze-Fichet, 2000; Doazan \& Eckert, 2014).

Nowadays, the debate on the risk of professional downgrading remains current and open; nonetheless, most studies either focus exclusively on the determinants of country-level education-work mismatch or tend to assess the effects produced on earnings, productivity, career mobility and job satisfaction (Brynin, 2002; Lemistre, 2014) or on specific sectors of activity, such as public service (Moullet, Véro \& di Paola, 2005). To date, cross-national studies based on a spatial approach to this phenomenon are even scarcer and usually limited in identifying convergences and/or differences in the factors driving over-education across countries (Verhaest \& van der Velden, 2013; Budría \& Moro-Egido, 2018).

This paper aims to add to the existing literature by conducting a comparative analysis of professional downgrading in France and Italy at an infra-national level. The decision to analyse this phenomenon in France and Italy is based on two factors. Firstly, more recent downgrading of higher education graduates has been substantially shaped by the second education explosion in the 1990s, namely, by the expansion of access to higher education and an increase in the number of tertiary graduates. In this regard, in the European context, France and Italy take up peculiar positions: France because its pathway almost perfectly matches the average of European countries, and Italy because it is the country where this second education explosion occurred most recently. Moreover, in Italy the proportion of higher education graduates among younger generations is the second lowest in Europe (28\% for people aged 30 to 34 in 2018, although this percentage has tripled in 25 years).

Secondly, France and Italy are interesting to compare because of their different urban mesh. Urban structures can play an important role in the geography of higher education graduates' downgrading. In general, very large cities tend to concentrate a significant proportion of managerial positions and higher-level intellectual professions. This is the case in France, where intellectual, management and decision-making functions converge (Van Puymbroeck, 2010), particularly in Paris and the Île-de-France region, where more than a third of these jobs are found (Aubry \& Léger, 2015). On the other hand, the urban network in Italy is very different from that of France, which is characterised by a hyper-concentration of political, economic, cultural and media powers in the Parisian agglomeration and, to a much lesser extent, in a few regional metropolises (Lyon, Lille, Toulouse, Nice) ${ }^{4}$. In Italy, if two cities dominate the urban hierarchy (Roma and Milano), there are also several large cities of importance on the European stage (Firenze, Torino, Napoli, Venezia, Bologna, etc. $)^{5}$ and more than a hundred cities of between 30,000 and 200,000 inhabitants, often active, well-equipped, and even welcoming for a few higher functions (universities; major head offices, such as the Benetton headquarters in Treviso) (Delpirou \& Rivière, 2013). As a result, managerial jobs are better distributed in Italy than in France. Finally, in Italy there is no 'diagonal of the void'. ${ }^{6}$ There is, however, a significant north-south division.

Based on this comparative approach, our study investigates the professional downgrading in France and in Italy, especially with respect to access to managerial positions, (1) exploring territorial disparities

3 The term EU-15 refers to the 15 member states of the European Union before the new member states joined the EU. For these countries, statistical series are available for the last twenty-five years.

4 The territories mentioned in this article for France are shown on map Al in Annex 1.

5 The territories mentioned in this article for Italy are shown on map A2 in Annex 2.

6 The 'diagonal of the void' (diagonale du vide) is a broad band that crosses metropolitan France from north-east to south-west, within which population densities are relatively low compared to the rest of France. 
within and across countries at a small regional level and (2) examining some implications produced by this phenomenon such as the redistribution of higher education graduates.

The differences between these two countries suggest a priori, on the one hand, that the downgrading of higher education graduates is less evident in Italy than in France and, on the other hand, that this expected result, joined to the more balanced urban mesh in Italy, should lead to less marked territorial disparities in this country compared to France. We will show that this is not the case.

\subsection{Theoretical Background: Determinants and Consequences of Professional Downgrading}

In Europe two main strands of literature have, over time, investigated the implications produced by the increase in professional downgrading in general, and by that of higher education graduates in particular. The first strand highlights the effects shaped by a greater number of highly educated workers that accentuates the phenomenon of 'queuing' within the labour market (Salais, 1980), where candidates are placed according to their educational qualifications and also according to the theory of competition for employment (Thurow, 1975). Conforming to this postulate, the growing number of candidates for managerial positions has increased the 'queue' for this type of position. As a result, the lowest ranked individuals are strongly encouraged to choose between waiting for a job corresponding to their level of qualification (and in this case remaining unemployed or being inactive) or changing 'queues' and applying for a job where the required qualifications are lower than the education level possessed. In this case, they displace even further those whose level of qualification corresponds to the jobs of this 'queue,' inducing them to confront the same dilemma.

This empirical evidence seems to have dominated mainly in France, where the research conducted since the second half of the 1990s has focused on the risk factors of downgrading, analysing the socio-demographic characteristics of individuals (the size of the municipality of residence, sex, mode of residence, father's profession, etc.) (Nauze-Fichet \& Tomasini, 2002), the dimension of the job held (sector of activity, size of the employer, type of contract) (Giret, Nauze-Fichet \& Tomasini, 2006), and the level of education and/or training (Giret, Lopez, \& Rose, 2005). Moreover, detailed studies, such as those resulting from the use of the generation surveys carried out by the Centre for Studies and Research on Qualifications (Céreq), have documented the trajectories of individuals with regard to access to jobs (Nauze-Fichet \& Tomasini, 2005).

Another strand of literature reverses this logic related to the professional downgrading pointing to the shortage of skilled jobs. This is precisely what Italian research does, often focusing on the structural factors driving over-education that stem from the development of activity sectors requiring less-qualified workers to the detriment of activities in the advanced tertiary sector (Bernardi \& Ballarino, 2014). Some studies have explored the diffusion of the professional downgrading in Italy in the area of public service during the 1990s (Argentin \& Triventi, 2011) when some institutional reforms and the significant presence of the baby boomer generation in management positions had further reduced recruitment opportunities for higher education. The development of the private sector has certainly helped young Italian graduates to access employment, but most often they occupy intermediate professions (Fullin \& Reynieri, 2015).

Other studies have shown that structural imbalances in the labour market play a greater role in determining over-education rates than does the education system. In other words, there would not be a surplus of higher education graduates in Italy, but rather there would be an insufficient number of mediumor high-skilled jobs (Ballarino \& Schizzerotto, 2011; Argentin \& Ballarino, 2014). Not surprisingly, the spatial dimension has also been emphasised in this country given the development gap between the northern and southern regions. Iammarino and Marinelli $(2015,2017)$ have investigated interregional migrations in Italy, examining the relationship between over-education in workers and spatial mobility, while Meliciani and Radicchia (2016) have measured the effect of migration on the education-to-work transition. Both of these studies apply econometric models and seek to identify individual characteristics (sex, type of training, father's level of education, region of origin, etc.) related to the risk of experiencing internal migration.

Concerning the geographical implications of the downgrading, few studies have examined this feature but only through analysis of the individual trajectories and their determinants. Plassard argues that, 'a part of over-education would result from trade-offs between employment and the advantages of the place of residence' (Plassard, 2015, p. 52) and in line with this assertion, scholars have compared levels 
of downgrading of one country with another. For example, empirical evidence has documented an increase in the rates of over-education on the labour market in Portugal, especially between 1985 and 1992 , and in the Netherlands between 1960 and 1995 (Brynin, 2002; Chabault, 2008). Nevertheless, to our knowledge, the demographic translation of the downgrading on geographic disparities has not yet been explored at the sub-national level. Several questions regarding over-education remain to be addressed by an in-depth and systematic spatial analysis.

Indeed, when tensions within the labour market are so strong that they force workers to occupy a job for which they are overqualified, the issue of residential mobility within a region or a country - but also externally (migration to a foreign country) - is essential.

Internal and international migration can play an important role in shaping regional differences related to the phenomenon of downgrading. At the individual level, some studies show that interregional migrants have lower rates of over-education than local populations (González-Leonardo \& Gay, 2019); conversely, over-education seems to be higher for international immigrants than for the native population (Hidalgo, Calderón \& Pérez, 2006). On the other hand, a growing stream of research at the national and regional levels is exploring the impact of internal migration, by level of education attained, on the redistribution of human capital, focusing on the changes this phenomenon implies in the number and composition of skills in both the regions of origin and of destination (Faggian, Rajbhandari \& Dotzel, 2017; Bonifazi, Heins, \& Tucci, 2018). A recent study has shown that in Spain the educational selectivity of internal migrants has produced different internal migration patterns related to the existing territorial imbalances of this country. In particular, the growing mismatch between workers' skills and the labour market, and strong competition for the few qualified jobs available, has increased migration of graduates from some inland regions towards more economically developed regions over time, while out-migration rates of less educated individuals have remained stable (González-Leonardo, et al. 2020).

Conversely, by examining the effects of internal mobility on regional labor markets, some authors have revealed mixed findings in Italy. For interregional migration flows of low-skilled workers, the spatial differences in the unemployment rates are reduced. In contrast, south-north flows of high-skilled workers have had a negative impact, increasing unemployment rate differentials and deepening the disparities between northern and southern regions and provinces (Basile, Girardi, Mantuano \& Russo, 2019). This article is devoted more precisely to the 'geographical translation' in Italy and France of these residential mobilities which is partly related to the 'fear of downgrading' (Eckert, 2014, p. 87) of higher education graduates.

\section{Methodology}

To characterise and then measure downgrading, several methods have been used over the past forty years. The first, the normative approach, consists of establishing a priori a correspondence table between 'the diplomas which usually match to a profession (entry by profession) or, conversely, the profession or professions traditionally associated with a level of education (entry by diploma)' (Forgeot \& Gautié, 1997, p. 55). The second method, the statistical approach, refers to a correspondence table between diploma and profession based 'on a criterion of a statistical nature in the sense that it takes account both of the relative importance of social categories at each level of education, and, symmetrically, of the relative shares of the various diplomas in each social category (without referring to a specific threshold)' (Forgeot \& Gautié, 1997 , p. 56). In this way the norm is statistically defined. Finally, there is a third subjective approach (Di Paola \& Moullet, 2012), which is based on the sense of satisfaction that individuals experience in their professional positions and social categories related to their level of education.

To perform our spatial analysis in France and in Italy we adopted the normative method, which proposes downgrading measures for a considerable number of diploma levels (Lemistre, 2014). Nevertheless, since our purpose is to provide a measure of downgrading on a small sub-national scale, we have limited the number of categories used to characterise diploma level and socio-professional category.

Concerning diplomas, we gathered three categories of workers and brought them together within the same category: those whose highest diploma is lower than a baccalaureate; those whose highest education level is a baccalaureate degree, including general, technological or professional degrees; and, finally, all active higher education graduates, whatever the number of years of study.

On the employment side, we have differentiated two main categories. The first includes managers and higher intellectual professionals whose level of skill unequivocally corresponds to higher education; the 
second includes employees/workers whose required level of skill is still (and in principle) unequivocally below the baccalaureate.

Even though we are attempting to expand the knowledge of downgrading on a detailed geographic scale, our study is mainly based on an analysis of the following simple indicators:

- the proportion of managers among workers with higher education qualifications aged 25 to 54 , which measures the proportion of higher graduates who access a job corresponding to their level of education/qualification;

- the proportion of employees/workers among the same active graduates aged 25 to 54, which assesses the proportion of these graduates that unambiguously occupy a downgraded professional position in relation to their level of education.

We analysed indicators for Italy and France across time and space even though the implementation of the comparison between these two countries has limitations.

The first one stems from significant differences between professional nomenclatures in the two countries. Rather than trying to reconstruct categories of professions exactly identical to the ones existing in France, we have gathered those that are significant with respect to the topic of our analysis in each country. For executives/managers, we regrouped functions and jobs which 'normally' target higher education graduates. ${ }^{7}$ For workers/employees, we brought together functions and jobs which, if occupied by tertiary graduates, would undoubtedly represent a clear professional downgrading. ${ }^{8}$ In order to clearly differentiate these two social groups (managers on the one hand, and workers/employees on the other), certain socio-professional categories, which can include significant proportions of higher education graduates, baccalaureate holders and non-baccalaureate holders, have been excluded from our field of study. These are mainly intermediate professions (for example, senior technicians, who may hold a short-cycle higher education qualification, but might also be non-higher education graduates who have benefited from social promotions), artisans and traders, farmers and the military.

The second limitation concerns the sub-national divisions adopted for France and Italy. For France, we have focused on the arrondissement, which is a sub-departmental administrative unit (three to four per department) whose name corresponds to the main city where administrative functions are concentrated (sub-prefecture or prefecture when the capital of the arrondissement is also that of the department). There are around 330 in mainland France. Their number may vary over time depending on local territorial redevelopments, although this is quite rare. Statistically, these districts have the advantage of dividing France into a sufficiently large number of spatial units to distinguish between the living areas of cities and large, medium and small towns, with rural towns, while providing large enough numbers of individuals to produce robust descriptive statistics. In Italy, these administrative units do not exist. However, we can refer to the provinces (110 provinces in 2011), which have the same advantages as the French districts in studies that explore spatial disparities.

Finally, the time periods compared are different. While for France it is possible to construct a harmonised series of professional downgrading indicators since 1968, for Italy this is only possible for the years 2001 and 2011. Indeed, the available data does not allow us to construct indicators that might intersect the educational level and socio-professional category for the years 1981 and 1991 due to changes in occupational classifications. Nevertheless, this does not detract from our approach of comparing the sub-national intensity of downgrading since the beginning of the significant growth in the proportion of tertiary graduates in the labour force aged 25 to 54 . Given the demographic inertia, a time lag is needed between the moment when the share of higher education graduates within a generation increases and the moment when this phenomenon materialises within a set of three generations. The earlier emergence of this phenomenon in France explains why we have gone back to 1982 to draw broad outlines of the initial situation, whereas starting from 2001 is pertinent for the case of Italy.

Despite the methodological difficulties encountered in ensuring a comparison between France and Italy, the changes observed over time have allowed us to obtain solid findings.

We used available data from the National Institute for Statistics and Economic Studies (INSEE) for France and from National Institute of Statistics (ISTAT) for Italy concerning people aged 25 to 54 . This

7 Professional, intellectual, scientific activities requiring higher skills or artistic activity; management of a company or management of public or private organisations.

8 These categories concern occupations that involve simple and routine tasks requiring manual labour or service functions or require skills at the second ISCO skill level (i.e., stationary plant and machine operator assemblers, drivers and mobile plant operators). 
aggregated age category has the advantage of bringing together most of the working population. Its reduction to three generations also allows us to measure the changes between two generations that completely differ with respect to the phenomenon of downgrading. Thus, by examining this age group it is possible to compare workers aged 25 to 54 at the beginning of the 1980s with those of the 2010s, two sets completely separate from a generational point of view. Indeed, during the 1980s the number of baccalaureates, and then the number of students, began to significantly increase in France, producing a significant change in the composition of the working population. Also, at the beginning of the 1980s, a policy of decentralisation was implemented in France to rebalance power between the central administrations in Paris and the territorial administrations in the provinces.

\section{Results}

\subsection{Evolution of educational levels at the national level in Italy and France}

Before exploring the territorial differences in professional downgrading in Italy and France, we present the trend at the national level, examining the same indicators used at the sub-national level. This framework allows us to better understand this phenomenon at the level of the entire country and, thus, to better illustrate the geographical disparities.

In France as in Italy, with the growth in the proportion of tertiary graduates in the working population (Figure 1), the share of these graduates aged 25 to 54 who occupy positions as manual workers or employees has increased considerably: It has risen from 7\% to 21\% between 1982 and 2015 in France, and from $8 \%$ to $22 \%$ in just 10 years in Italy (from 2001 to 2011). At the same time, the proportion of the higher education graduates aged 25 to 54 in managerial positions has dropped from $45 \%$ to $36 \%$ in France, and from $70 \%$ to $55 \%$ in Italy. In these two countries, the extent of this decrease is therefore comparable to the increase in the proportion of downgraded higher education graduates in the labor market. These two symmetrical trends both highlight the same phenomenon: the growing tension related to access to jobs corresponding to the highest levels of education and/or qualification.

Figure 1. Evolution in France and Italy of the proportion of higher education graduates among the active population (employed or not) aged 25 to 54

$\%$ of people

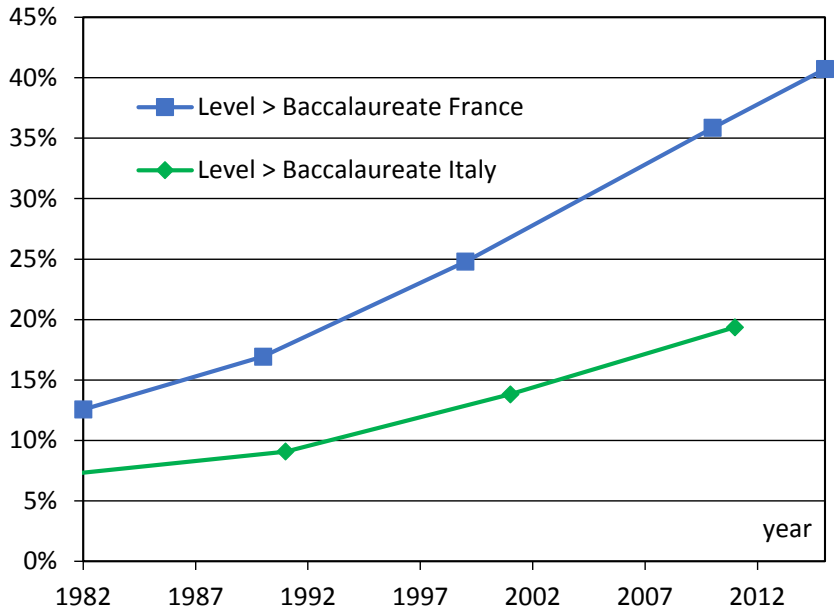

Source: Insee, French Population Census; Istat, Italian Population Census. Own elaboration

The entry into the labor market of ever more qualified generations, and the departure of older ones possessing lower education levels logically leads to an increase in the proportion of workers (employed or not) who have earned a tertiary level degree. Thus, in France, between 1982 and 2015, the share of workers aged 25 to 54 with a higher level of education more than tripled, from 13\% to 41\% (Figure 1). But at the same time, the number of working people in this age group occupying managerial positions has only increased by a factor of x2.4. Among higher education graduates, competition for access to managerial jobs has therefore intensified considerably: In 1982 there were 2.1 million higher education graduates among workers aged 25 to 54 and 1.6 million managers in this age group, a ratio of 13 higher 
education graduates for every 10 executives. In 2015, this ratio rose with 9.1 million higher education graduates for every 3.9 million executives. In Italy, where the share of workers aged 25 to 54 with a higher education level only doubled between 1981 and 2011 - from 9\% to 19\% (Figure 1) - the ratio between the number of managerial jobs and the number of higher education graduates was much more favorable than in France. In 2011, there were 3.3 million managers among workers aged 25 to 54 for 3.9 million higher education graduates in Italy, a ratio of 12 higher education graduates for every 10 executives.

Nevertheless, in Italy the decrease in the number of managerial jobs between 2001 and 2011, which was also exacerbated by the crisis of 2008 that hit Italy particularly hard, combined with the increasing flow of higher education graduates, probably explains the surge in downgrading for this category of workers. Indeed, the number of executives aged 25 to 54 lost 250,000 units in ten years, while the number of graduates gained one million.

To sum up, in France, the increase in the share of higher education graduates within each generation has led to a rise in the proportion of active people with a tertiary education level. This trend has contributed to the downgrading of all those who do not attain higher education: In 1982, 41\% of managers did not have tertiary level qualifications; in 2015, that percentage is only $15 \%$. While it was possible even thirty years ago to access managerial positions without a tertiary level diploma, this is not true today. In 2015, only higher education graduates can hope to access professional functions.

However, the increase in the number of tertiary graduates has been greater than the increase in the number of jobs for which such qualifications are required; consequently, their chances of becoming managers have decreased quite markedly. As a result, a significant proportion (one in five) of workers who have obtained a tertiary level diploma are employed as manual workers or employees. In other words, the increase in the number of higher education graduates has reduced their access to managerial functions and, therefore, effectively blocks entirely any possibility of becoming a manager for a person who chooses not to pursue higher studies. Briefly, the increasing and respectable ambition to pursue higher education has translated into a strengthening of inequalities in access to managerial functions and a weakening of the conversion of university qualifications in the job market.

This pattern is completely comparable in Italy. Managerial positions are becoming increasingly reserved for higher education graduates: In 2011, 66\% of executives were tertiary-level graduates, compared to just half $(49 \%)$ ten years earlier. This reality has also intensified competition for these types of jobs among higher education graduates which, with the consequent drop in the proportion of managers among tertiary graduates, has increased professional downgrading.

The situation has become critical over time: Maestripieri and Ranci (2016) write that Italy, "Is not a country for graduates". Furthermore, it is not impossible that the figures on downgrading underestimate the reality. Indeed, especially since the crisis of the late 2000s, emigration from Italy has increased significantly, and higher education graduates have represented an important percentage of these outflows (Bonifazi \& Heins, 2019; De Rosa \& Strozza, 2015; Dubucs, Pfirsch, Recchi \& Schmoll, 2017). In general, this skilled migration has reduced the demographic pressure on managerial jobs in Italy. Nonetheless, the Italian job market only partially succeeds in offering suitable positions to the many tertiary-level graduates. Consequently, these individuals are often forced to choose to either accept a downgraded job in their own country or to expatriate.

These departures have consequences for the statistics: If in Italy the migration of higher education graduates due to a lack of professional positions corresponding to their qualifications were not a reality, the proportion of managers among higher education graduates would be lower, while the proportion of intermediate occupations and workers/employees would be higher.

Therefore, the migration of graduates mitigates, in a way, these findings. Nonetheless, the figures presented lead unambiguously to the fact that Italy is currently experiencing difficulty in ensuring the conversion of tertiary-level diplomas in the labor market, despite the fact that less than $30 \%$ of the younger generations reach this education level ${ }^{9}$.

9 This proportion likely underestimates the real share of tertiary graduates within a generation. Eurostat statistics for each country only relate to the resident population within each of them. And if, as we have mentioned, the rate of emigration of graduates is significant, these departures of higher education graduates lead to an underestimation of the growth in the number - and probably the share - of higher education graduates among 30 to 34 years old. If, in Italy, this statistic lags behind those of all the other European countries, it is perhaps also because some of its graduates, or even most of its graduates (engineers, researchers, doctors, architects, etc.) no longer reside there. 
However, in France and Italy, depending on the territory, this difficulty in ensuring a suitable conversion of university degrees in the labor market can be quite unequal. Statistics show significant disparities between those territories integrated into the globalization process (the big cities in France, the northern regions in Italy) and the rest of the country. This is precisely what the sub-national spatial analysis shows in this paper.

\subsection{Slight territorial disparities in Italy as in France with a downgrading rate below $10 \%$.}

In the early 1980s when only $7 \%$ of higher education graduates aged 25-54 were employed as manual workers, France was a homogeneous country with regard to the local capacity for higher education graduates to reap the rewards of their educational capital in the job market. In 7 out of 10 arrondissements, more than $35 \%$ of higher education graduates were able to access managerial jobs (Figure 2 ). If, at the beginning of the 1980s, access to managerial positions was certainly not equal everywhere - with the Paris region and, to a lesser extent, regional capitals already being an obligatory passage for many higher education graduates - the possibility of making use of a tertiary-level education presented only moderate disparities according to territory. Only in rural districts, such as those of the Massif Central (a mid-mountain area which is quite isolated), were the professional opportunities scarce for working people with higher education qualifications. In all parts of France, the risks of a professional having to downgrade (as a manual worker or over-qualified employee) were low.

With the exception of 27 arrondissements (more or less) throughout France, in Paris as well as in the arrondissements of small and medium-sized towns, and even in the rural arrondissements, the proportion of higher education graduates occupying worker/employee positions did not exceed 10\% (Figure 3).

Figure 2. Proportion (\%) of executives among tertiary graduates aged 25-54 in 1982

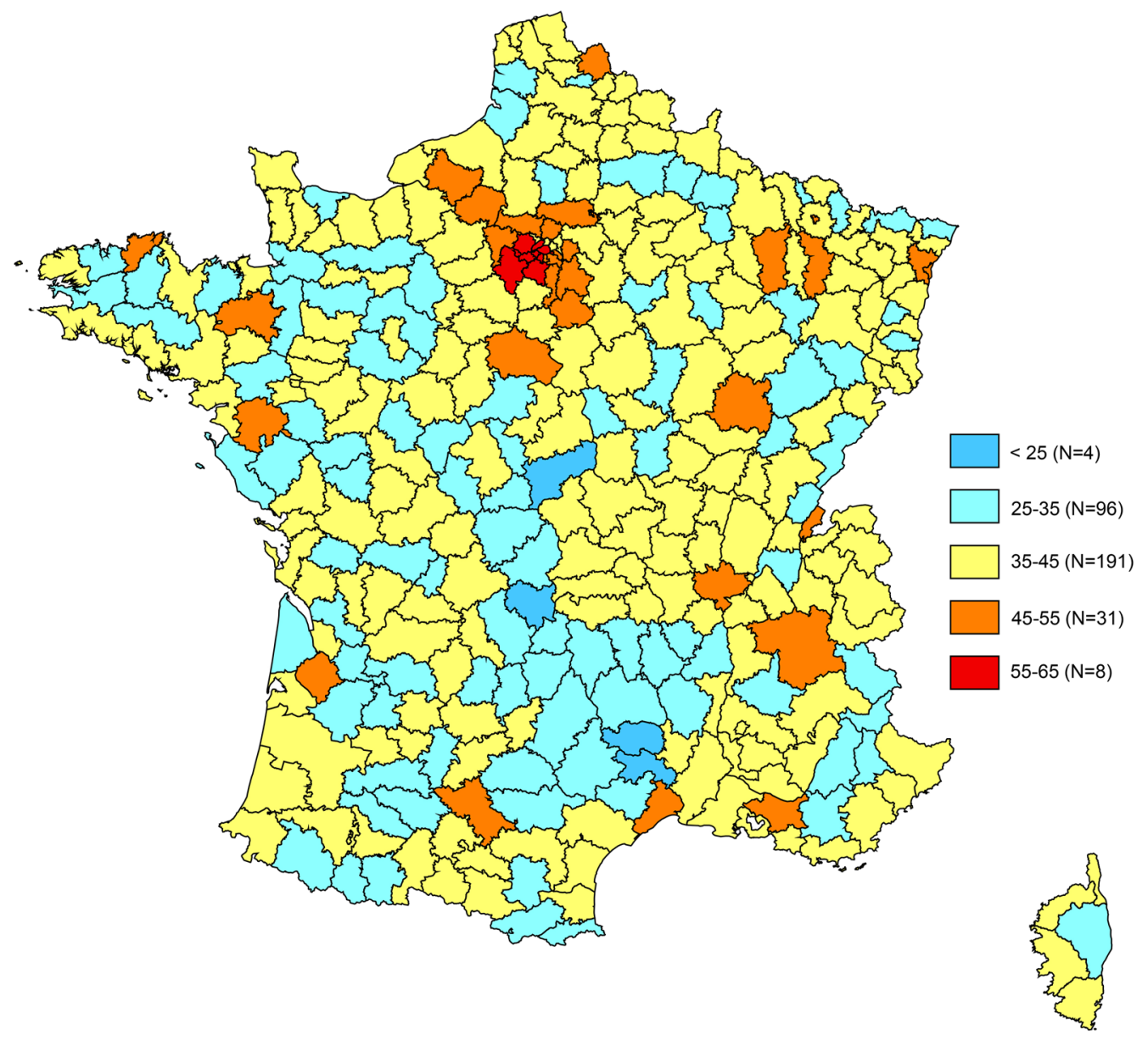

Source : Insee, 1982 French Population Census. Own elaboration 


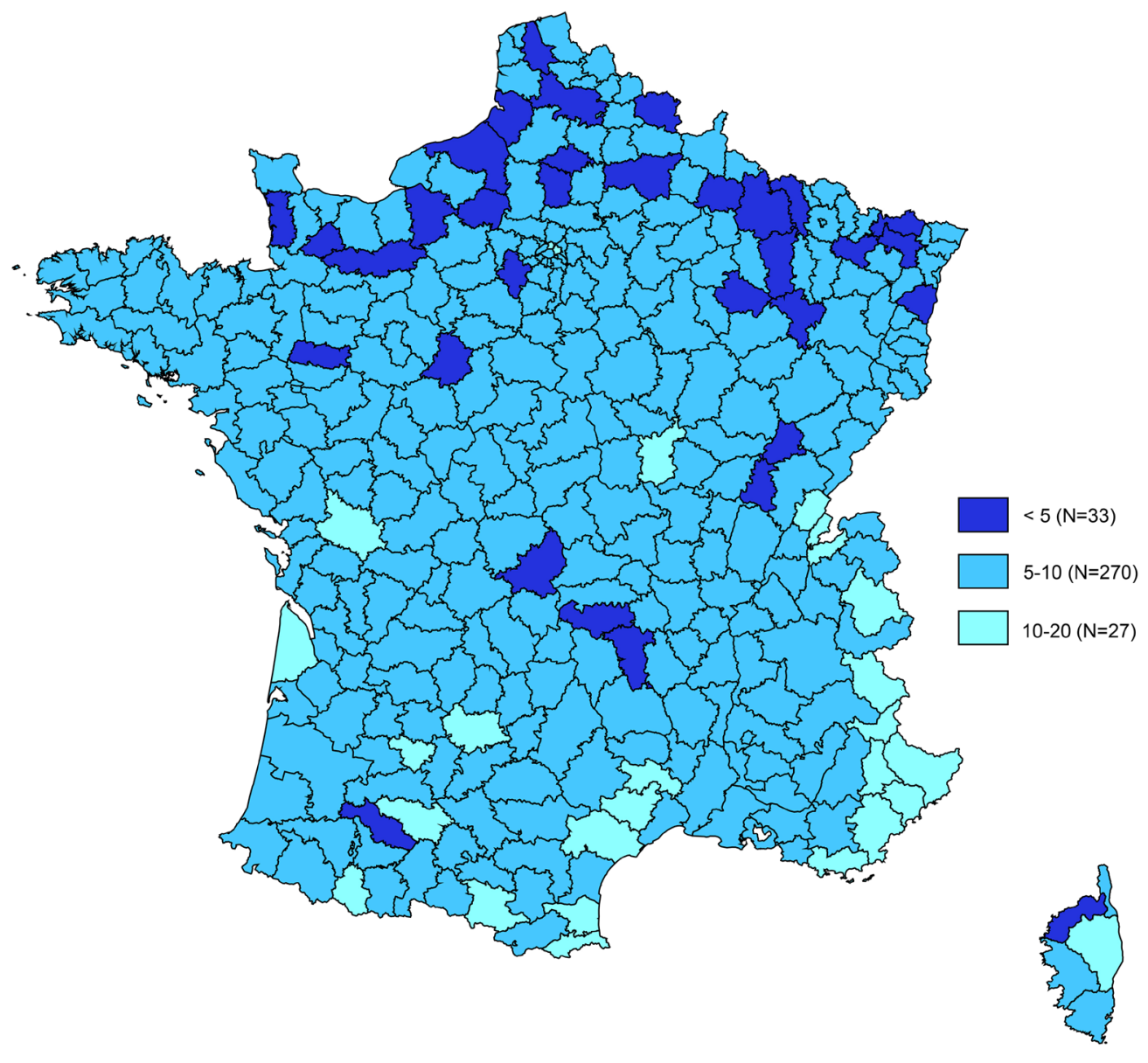

Source: 1982 French Population Census. Own elaboration

The same observation could be made in Italy in 2001, when only $8 \%$ of higher education graduates were manual workers or employees. Undoubtedly, at the beginning of the 2000s in northern Italy, which is the most productive area of the country, the proportion of managers among tertiary graduates was the highest on average. In all the regions of the North (Piemonte, Emilia-Romagna, Friuli-Venezia Giulia, Veneto, Lombardia, Toscana and Liguria) with the exception of Valle d'Aosta, this proportion was higher than or equal to the national average (70\%).

However, between the north and the south of the country, on a regional scale, the differences remain relatively small (from $73 \%$ in Piemonte to $63 \%$ in Basilicata), as well as at the provincial level (Figure 4). In the northern regions, not all the provinces have a higher proportion of managers among tertiary-level graduates than the national average. Nevertheless, the differences are limited except in very rare cases, such as in Piemonte (76\% of managers with tertiary degrees), where the province of Torino, which holds more than half the managers in the region, weighs considerably in the regional average. The difference in the extreme regional values related to the proportion of manual workers or employees among higher education graduates was also small (from 5\% in Campania to $10 \%$ in Valle d'Aosta). This is also the case at the provincial level (from 3\% in the province of Caserta, in Campania, to 11\% in Savona, in Liguria). Nevertheless, the spatialization of this indicator reveals the first surprise: In the southernmost regions of the country the values are lowest (Figure 5). In other words, while in the southernmost part of the Mezzogiorno ${ }^{10}$ higher education graduates have the least chance of working in a profession corresponding to their level of education, nevertheless, they also represent the smallest proportion to occupy clearly downgraded professional functions. In Campania, Calabria, Basilicata, Puglia and Sardegna, this proportion is lower than the national average (7\%). In the northern regions, a similar situation can be observed only in Piemonte. 
Figure 4. Proportion (\%) of executives among tertiary graduates aged 25-54 in 2001

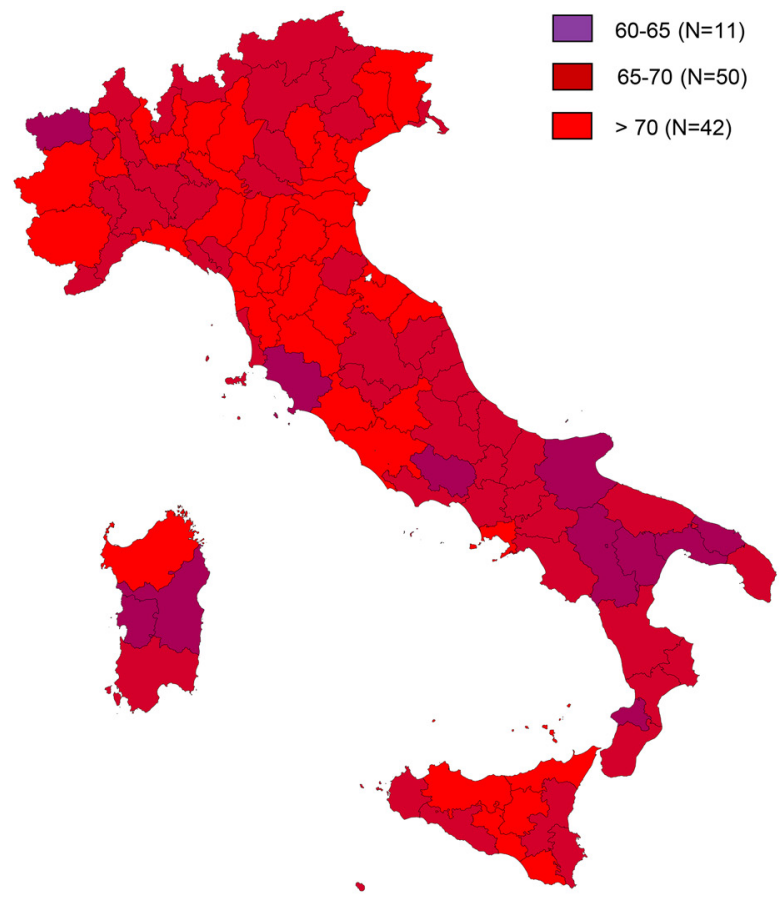

Source : Istat, 2001 Italian Population Census. Own elaboration

Figure 5. Proportion (\%) of manual workers among tertiary graduates aged 25-54 in 2001

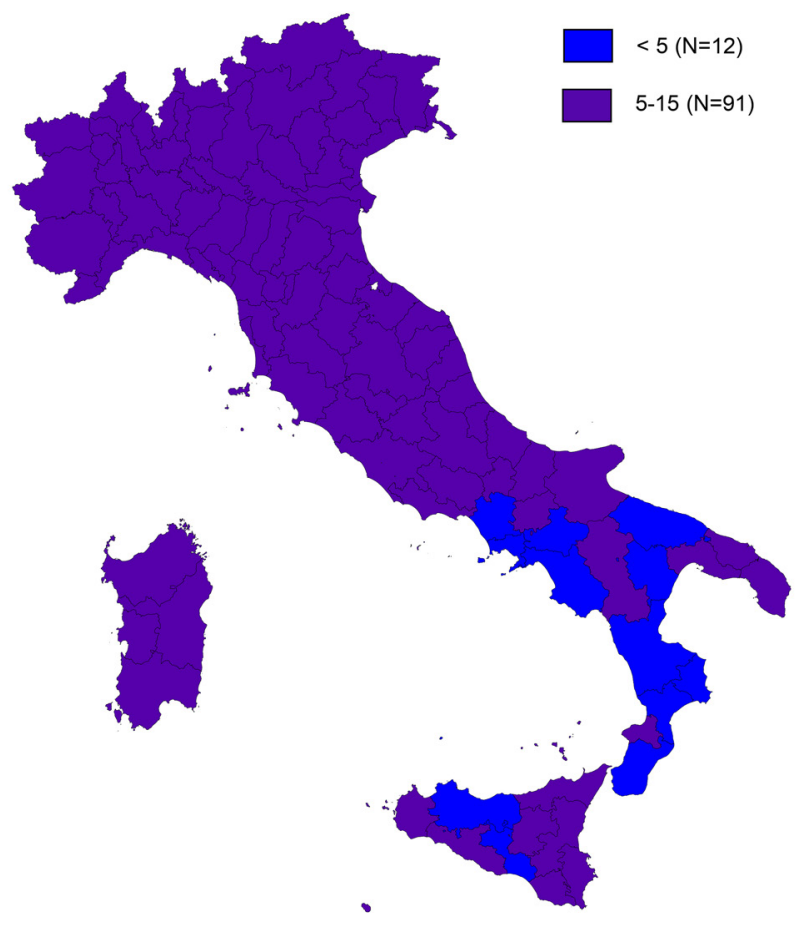

Source : Istat, 2001 Italian Population Census. Own elaboration 
These results, and the maps for Italy, cannot be properly apprehended without considering internal migration, the dominant historical movement of populations along the axis of south to north. Houdaille had already echoed it in 1970, insisting that, "these migrations do not depend solely on economic factors", but that, "to reverse this trend it is quite a state of mind that would have to be transformed" (Houdaille, 1970, p. 1091). Recent studies confirm that this movement of individuals in Italy involves not only workers but also more qualified young people (Basile et al., 2019). Furthermore, while the reasons for migration to the north of the country cannot be reduced solely to the economic aspect, it remains an important explanatory factor. In fact, since the early 1970s the value of gross domestic product (GDP) per capita in purchasing power parity in the south of Italy corresponded to only $70 \%$ of that of the central and northern regions (Bonifazi, 2015). Pugliese (2015) also indicates that, at least for current internal migrants from the regions of southern Italy, the conditions of departure are not much different from those experienced by the earlier wave of workers who left with their 'cardboard suitcases'. Today, "many university graduates leave their regions with the equivalent of the cardboard suitcase, that is to say with little hope, little security and very low chances of finding a stable job suited to the university title possessed" (Pugliese, 2015, p. 34). The statistical translation of these migratory movements on the map shows that in 2001, in Northern Italy, the proportion of higher education graduates who held managerial jobs was greater than in Southern Italy. On the other hand, in the southernmost regions the share of higher education graduates occupying manual worker/employee positions is the lowest.

Internal migration explains this apparent paradox. Higher education graduates from the southern regions have the opportunity to try their luck in the northern regions, which consequently reduces the proportion of higher education graduates in the South occupying downgraded professional functions. But these same graduates do not necessarily manage to find professional positions corresponding to their educational qualifications in the wealthier regions of the North, where the opportunities are more numerous but the proportion of graduates who occupy a position corresponding to their level of tertiary education is also greater. They therefore exert additional demographic pressure for the most qualified jobs, which in the receiving regions tends to increase the proportion of downgraded managers and also to decrease the proportion of managers among higher education graduates in these same regions. In 2001, however, this did not prevent the northern regions from presenting higher management rates among tertiary graduates than those in the South which, given the effect of internal migration on the value of this indicator, reveals how much more plentiful professional opportunities were in the north.

\subsection{Strong territorial inequalities in France (2015) and Italy (2011) with a downgrading rate above $20 \%$}

In France, "activities implying strong economic development potential and high decision-making content" are concentrated in Paris and in a small number of very large cities, and, "in these activities, the jobs are occupied mainly by managers" (Brutel, 2011, p. 2). Thus, at the start of the 2010s, $36 \%$ of executives resided in Île-de-France, one-third of which were in intramural Paris, and $20 \%$ of them were concentrated in the districts of the main provincial cities (Aix-en-Provence-Marseille, Lyon, Toulouse, Nice, Lille, Nantes, Montpellier, Strasbourg, Bordeaux, and Grenoble). In 2010, 56\% of the managerial positions in France were concentrated in the 25 arrondissements of Île-de-France and the 12 arrondissements covering the 10 main regional large cities (i.e. in just 37 of the 330 districts in mainland France). This order of magnitude remained the same in 2015. In Paris, nearly one in two workers aged 25-54 (45\%) is a manager, and this proportion is higher than $25 \%$ in eight other Parisian arrondissements. In the provinces, only the arrondissement of Toulouse reaches this value. In the districts corresponding to the other large provincial metropolises, the proportion of executives among the working population aged $25-54$ is only about $20 \%$. Elsewhere in the province, this proportion can fall significantly below $10 \%$. Therefore, it is in Paris and in the main regional cities that higher education graduates are most likely to find a job corresponding to their level of qualification. This is why they choose to live there.

Generally, in the employment areas of these cities the proportion of executives among higher education graduates reaches its highest values (Figure 6), and it is also in these areas that the risks of professional downgrading are the lowest (Figure 7). Not surprisingly, in the Paris region the proportion of executives among working people with higher education qualifications is highest. In 2015, it also reached 
or even exceeded $60 \%$ in the arrondissements of Paris and Boulogne-sur-Seine (a district contiguous to the one containing Paris). Moreover, it is only in the arrondissements of the Paris region that more than half of higher education graduates hold managerial positions. In the provinces, the maximum values are found in the large cities (Lyon, Toulouse, Grenoble, Strasbourg, etc.), where they exceed $40 \%$; this is twice the proportion in some arrondissements in Central and Northeastern France. This mapping of the percentage of executives among higher education graduates reflects, almost symmetrically, the proportion of downgraded higher education graduates. Except in the large metropolitan areas where this proportion is less than 10\%, it reaches or exceeds $20 \%$ in 299 of the 330 arrondissements in France. Professional downgrading is therefore experienced by at least $20 \%$ of higher education graduates practically everywhere in France, except in very large cities. This is an unprecedented partition of space that contrasts sharply with that which was observed thirty years earlier (Figures 6 and 7).

In thirty years, considerable spatial inequalities have therefore emerged between Paris and the major regional metropolises, as well as the rest of France. Certainly, here and there, some territories still managed to perform well, but these exceptions do not mitigate a particularly marked territorial split. And it is important to note that these territorial disparities, paradoxically, have widened since 1982 when administrative reorganization (geographical displacement of the decision-making power of Paris towards the territories) began to accelerate. The main beneficiaries of this policy are the large regional capitals. Conversely, within regions this has manifestly occurred to the detriment of rural livelihoods and of small and medium-sized towns.

Figure 6. Proportion (\%) of executives among tertiary graduates aged 25-54 in 2015

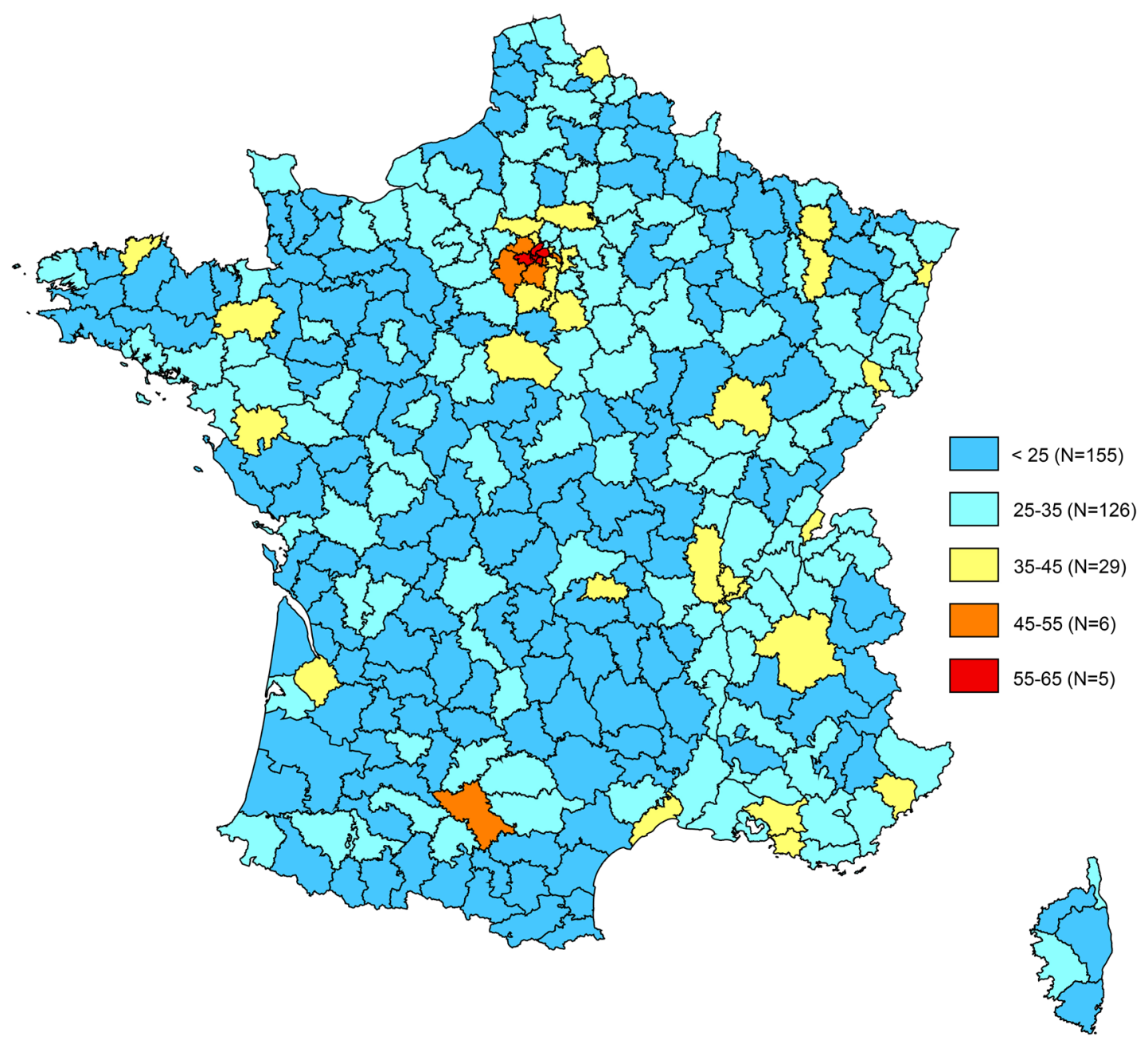

Source : Insee, 2015 French Population Census. Own elaboration 


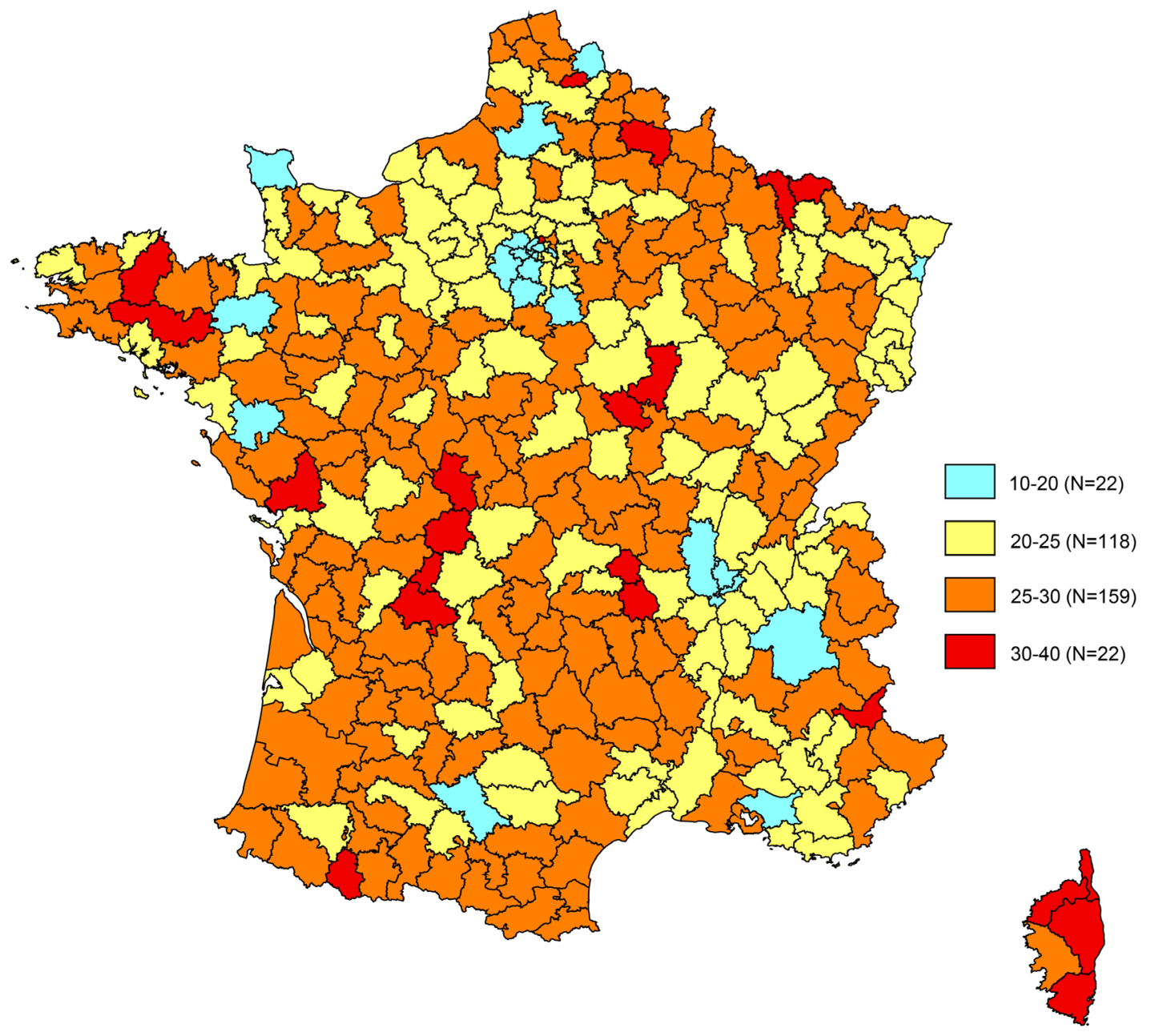

Source: 2015 French Population Census. Own elaboration

Managerial jobs are also unevenly distributed in Italy. In particular, in most parts of the South, they are scarce in number. In 2011, there were fewer managers aged 25-54 in the group of regions including Sicily (6.8\% of the 3.3 million executives aged 25-54), Calabria (2.8\%), Puglia (5.5\%), Basilicata (0.9\%), Molise $(0.5 \%)$ and Abruzzo (2.2\%) than in the region of Lombardia (18.9\%). These results are comparable to those for 2001. Within the regions, the province corresponding to the main city also concentrates a significant proportion of this type of employment. Thus: in Lombardia, the province of Milano concentrates 39\% of the executives of this region ( $48 \%$ if we add the provinces of Monza and Brianza, which until 2004 was part of the province of Milano); in Lazio, 80\% of managers aged 25-54 live in the province of Roma; in Piemonte and Campania, the provinces of Torino and Napoli also have more than half of the regional workforce in this category of workers. However, unlike in France, management jobs are much more evenly distributed among the territories. In France, in 2010, the districts of the 11 main metropolises brought together $56 \%$ of managers aged 25-54. In Italy, in 2011, the 11 provinces which hosted the most managers (Roma, Milano, Napoli, Torino, Bologna, Bari, Brescia, Firenze, Padua, Bergamo, Monza and Brianza) only concentrated $37 \%$ of this category of active workers. Gini coefficients summarize these very unequal territorial concentrations from one country to another ( 0.67 for France and 0.47 for Italy). But what this indicator does not reveal is the north-south division of the country. On the other hand, the increase in the downgrading rate and, at the same time, the reduction in the proportion of executives among working people with higher education qualifications highlight it clearly.

At the sub-national level, while the proportion of managers among working people aged 25-54 was greater than $60 \%$ everywhere in Italy in 2001, ten years later no regions present such data. In 2011, in 
only one province (Bolzano, in Trentino Alto Adige) does this proportion still exceed 60\%, in contrast with 2001, when all the provinces were in this situation.

But above all, in 2011 the regions and provinces of the South had managerial ratios for higher education graduates among the highest in the country (Figure 8). For example, in 2011 Puglia was at the same level as Piemonte (55\%), while ten years earlier 7 percentage points separated these two regions (66\% and $73 \%$ respectively). The same observation can be made at the provincial level: Whereas in Torino the proportion of executives among higher education graduates has dropped 20 points (from $76 \%$ in 2001 to $56 \%$ in 2011), in the province of Bari the decrease was more measured (from $67 \%$ to $56 \%$ ). It should be remembered that this statistical catching up took place while the GDP gap in purchasing power parity between the northern and southern regions remained remarkably constant over the entire period (Svimez, 2013). Therefore, a relative improvement in the conversion of higher education diplomas on the labor market in the southern regions cannot explain this statistical reversal. Rather, it is a combination of three factors: an increase in the number of higher education graduates in the labor market, the likely increase in migratory flows of young graduates from the South to the North, and a contraction of managerial jobs in the provinces of the northern regions. For example, in 2011 in Lombardia and Piemonte, there were fewer executives aged 25-54 than in 2001 (the 10-year deficits were 10,000 and 40,000, respectively). The northern provinces were therefore no longer able, at least in 2011, to absorb the growing number of higher education graduates, both those trained locally and those arriving from the southern provinces. The very marked deflation of the proportion of executives among tertiary graduates in the northern regions, and their lower values than those of the southern regions, reflects a particularly high strain on the Italian labor market.

Figure 8. Proportion (\%) of executives among tertiary graduates aged 25-54 in 2011

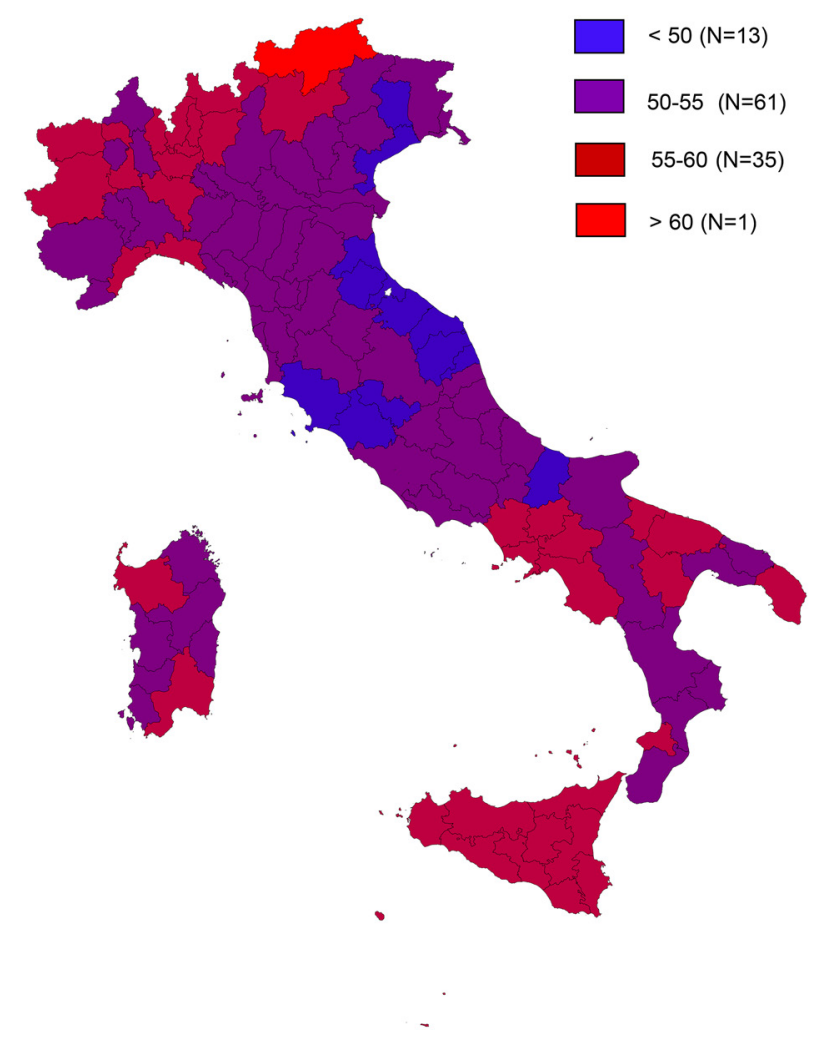

Source : Istat, 2011 Italian Population Census. Own elaboration

Migration tends to select those populations to remain in the South that manage to integrate well into the labor market. Therefore, the existence of this demographic bias in the interpretation of the data also explains why the proportion of downgraded tertiary-level graduates is lowest in the southern regions and provinces (Figure 9). It is, on average, less than 16\% in Basilicata, Puglia and Calabria, while it reaches $20 \%$ in Lombardia and Piemonte (two regions that welcome a "surplus" of graduates 
into a harsh local context). Within the regions, the values of this indicator are very homogeneous. The spatial disparities, therefore, primarily follow a north-south axis, but we do not note (as is the case in France) any significant sub-regional distinctions. In the North, the density of the urban network and the communication infrastructure between different towns within the same region promote commuting and, therefore, probably attenuate interprovincial differences.

Figure 9. Proportion (\%) of manual workers among tertiary graduates aged 25-54 in 2011

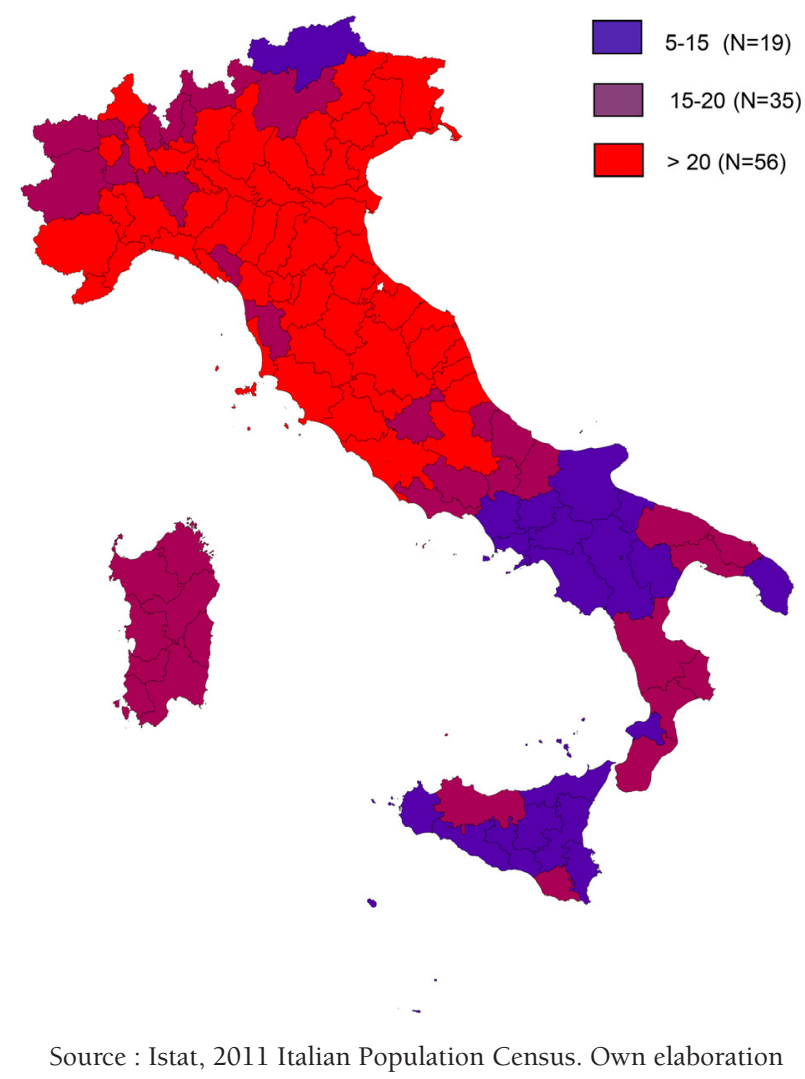

\section{Discussion and conclusions: Can the geographic concentration of skilled jobs be considered a model that is running out of steam?}

The faster growth in the number of tertiary graduates than that of the jobs requiring this level of education is now reflected in a decrease of the proportion of active higher education graduates who are able to convert their qualifications on the labor market. In turn, the rate of professional downgrading has increased: In Italy as in France, the proportion of workers aged 25-54 who are engaged as manual workers or employees is now over $20 \%$. The analysis of this phenomenon on a sub-national scale enhances this evidence. Our findings show that the rate of professional downgrading of highly educated workers has become very unequal depending on the region. The territories best integrated into the global economic context (the northern provinces in Italy; Paris and the large regional cities in France) are those with the greatest supply of highly skilled jobs and, consequently, offer higher education graduates a better chance of finding a job that corresponds to their level of qualification.

In both France and Italy, pursuing higher education often leads to geographic mobility. While a diploma can protect against unemployment, it does not guarantee a professional position that corresponds to the degree earned, nor does it necessarily allow the individual to reside where they would like. The ambition to be a member of management, therefore, can have a significant residential cost. For an Italian from the Mezzogiorno, it means going to live in the north of the country where the cost of living is higher and the opportunities are scarcer. It also often means accepting precarious living conditions - especially in terms of housing - when employment does not precede mobility. This is potentially even more true for those who relocate to other countries where they are more likely to find a job and/or salary corresponding to the expectations raised by the studies they pursued. 
This migratory response of active higher education graduates to territorial inequalities in Italy is already reaching its limits, as evidenced by the values of the provincial downgrading rates. In 2011, they were higher in the provinces of the North than in the South. This means that the northern provinces no longer have the capability of absorbing the ever-increasing number of workers in this category as they did in the early 2000s. In France, the downgrading rates of metropolitan areas, primarily Paris, are still significantly lower than those of other territories. The country's largest cities, therefore, seem to be able to accommodate working people with higher education qualifications. But for how much longer?

In France, the salaries of executives are certainly much higher on average than those of other social categories. But what about purchasing power when you have to find accommodation in a city where the selling price of housing exceeds 10,000 euros per square meter, as in Paris, or reaches 4,000 euros per square meter, as in Lyon, Bordeaux and a few other big cities? And what about the quality of life? Long before Covid-19 (which has only exacerbated this trend), in recent years, all the surveys carried out in France among executives/managers reveal a weariness for life in the large urban centres. The latest survey, which was carried out by Cadremploi in August of 2019 - a major recruitment site for executives - indicates that 8 out of 10 Parisian executives would be ready to leave Paris for an average-sized city. The stress of living in the capital, the cost of living, travel times, pollution, and very high rents are among the factors most often mentioned to explain the desire to live elsewhere. And even if these intentions will most often not be carried out, emerging phenomena are pointing in the same direction. There are more and more reports regarding early retraining of executives in the crafts, in education, or in other sectors that allow people to live someplace other than in the centres of the largest cities in France. It is no longer rare to hear students who have just finished their master's degrees talk about their desire to work in another profession, and very often a manual one. According to a survey carried out in France in 2015 by the Association for the Employment and Promotion of Executives (APEC) among 4,674 young graduates with a bac +5 level, $14 \%$ of them, "declared having experienced a professional change", and as the authors of this report point out, this reorientation may be, "an option imposed by a lack of opportunities and an unsuccessful job search" (APEC, 2015). The decrease in the proportion of higher education graduates holding managerial jobs in France and Italy would, therefore, be the result of increased tensions in the managerial market.

Pursuing a higher education level and accessing dominant professional positions (executives) is still widely considered to be the best way to enhance and control one's life course. Nevertheless, our results show that strong residential constraints weigh on workers with higher education qualifications due to the geographic concentration of these jobs, in Italy as well as in France. In addition, the very early reorientation of young graduates, "is also - unlike the initial orientation, marked by the weight of family influences - the opportunity to be an actor of his own destiny and to exercise a real personal choice" (APEC, 2015, p. 3). Therefore, to some of these people, the decrease in the proportion of executives among graduates of higher education could also be due to a generational shift in attitude. Younger generations may be more likely than their elders to distance themselves from the social pressure to pursue higher education and attempt to access the same social category as those who participated in their training (i.e. managers and those in so-called higher 'intellectual' professions).

So far, graduates of higher education have agreed to follow the jobs ( residential cost has become less and less profitable, with access to employment becoming increasingly difficult and the cost of living rising precisely where these jobs are concentrated. The health crisis linked to the SARS-Covid-19 epidemic, which particularly affected the northern provinces in Italy and large metropolitan areas in France, was also an opportunity to question this model. The development of teleworking in response to this health crisis has enabled a number of workers to move their work to the places where they reside. Granted, there is still a long way to go before jobs follow people ( jobs follow people »), but it is clear that at least part of the population seems ripe for a new settlement dynamic.

\section{Funding}

The project is funded by French and Italian Ministry of University and Research. 2019 Program Galileo N. G19-62 et N. 42057WJ ("Metropolisation in the Euro-Mediterranean region: an urbanisation model in crisis?". Project Coordinators: Gil Bellis and Maria Carella).

\section{Acknowledgements}

The authors would like to thank the anonymous reviewers for their helpful comments and suggestions which led to an improved manuscript. 


\section{Annexes}

Annex 1. Map of French regions (pre-2016 limits) and districts ("arrondissements") mentioned in the article

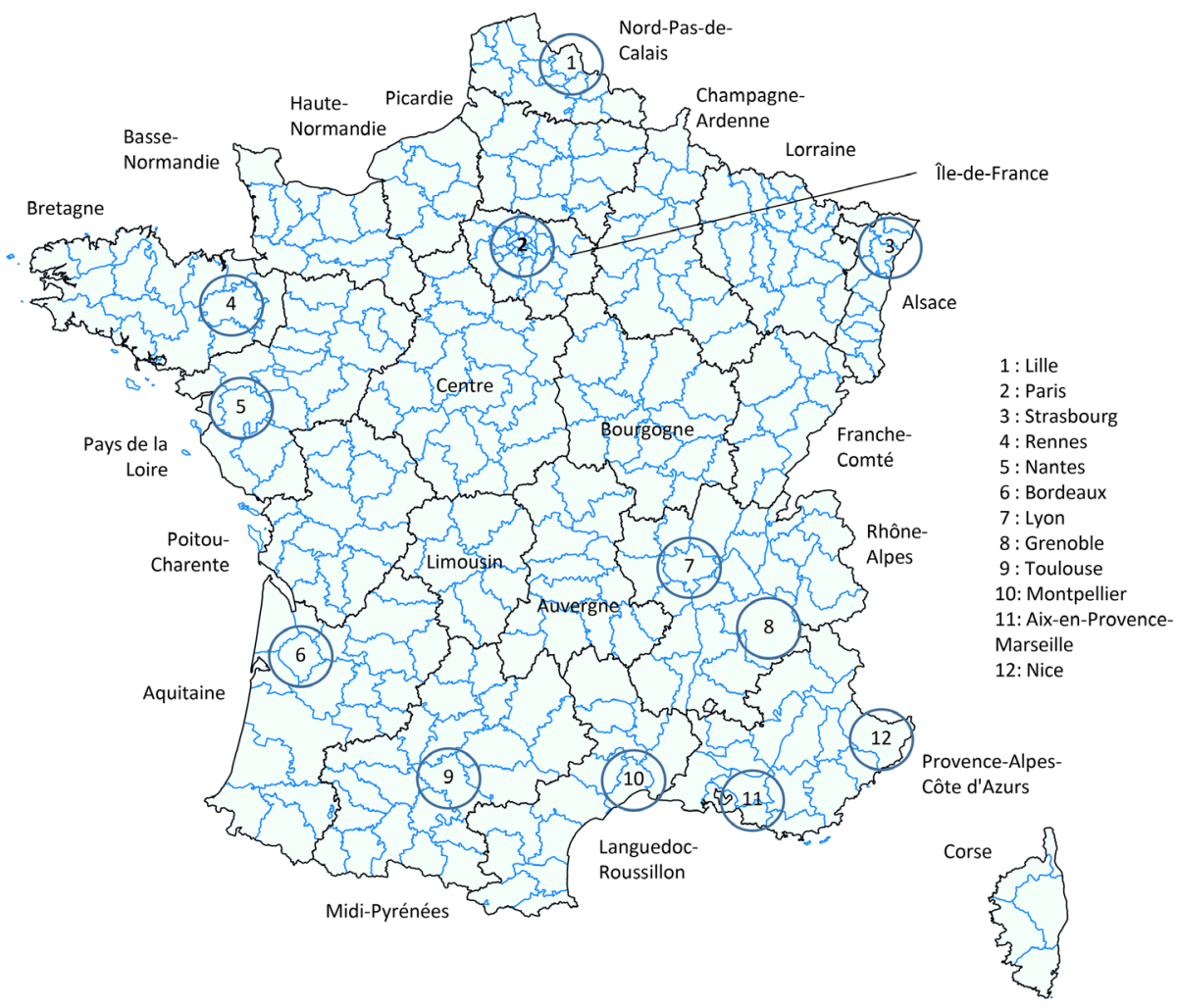

Own elaboration

Annex 2. Map of Italian regions and provinces mentioned in the article

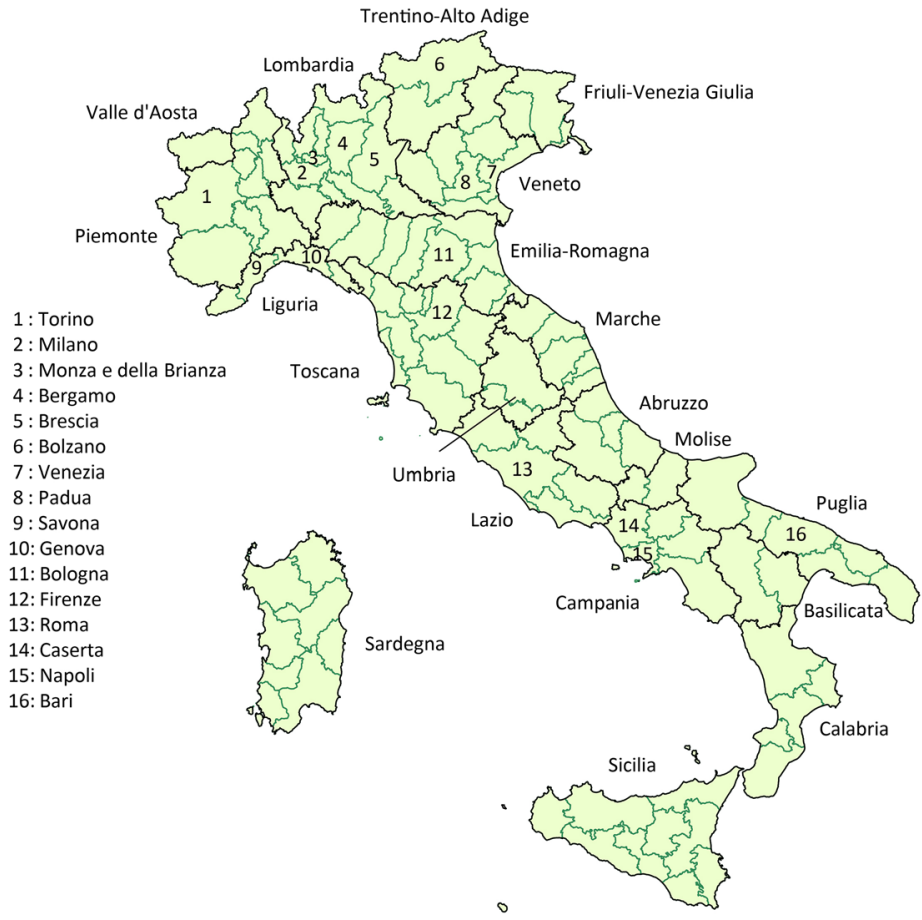

Own elaboration 


\section{References}

Argentin G., \& Ballarino, G. (2014). I rendimenti dell'istruzione: variazioni nello spazio e nel tempo. In P. Barbieri \& G. Fullin (Ed.), Lavoro, istituzioni, diseguaglianze. Sociologia comparata del mercato del lavoro (pp. 165-188). Bologna: Il Mulino.

Argentin, G., \& Triventi, M. (2011). Social inequality in higher education and labour market in a period of institutional reforms: Italy, 1992-2007. Higher education, 61(3), 309-323. https://doi.org/10.1007/ s10734-010-9379-6

Association pour la promotion et l'emploi des cadres (Apec) (2015). La réorientation professionnelle en début de carrière. Les études de l'emploi cadre, n. 2015-71 (septembre).

Aubry, B., \& Léger, J.-F. (2015). L'inégalité économique des territoires. Les écarts se creusent. Population E Avenir, 722(2), 4-7. https://doi.org/10.3917/popav.722.0004

Ballarino, G., \& Schizzerotto, A. (2011). Le disuguaglianze intergenerazionali di istruzione. In A. Schizzerotto, U. Trivellato \& N. Sartor (Ed.), Generazioni disuguali. Le condizioni di vita dei giovani di ieri e di oggi: un confronto (pp. 71-110). Bologna: Il Mulino.

Basile, R., Girardi, A., Mantuano, M., \& Russo, G. (2019). Interregional migration of human capital and unemployment dynamics: evidence from Italian provinces. German Economic Review, 20(4), 385-414. https://doi.org/10.1111/geer.12172

Bernardi, F, \& Ballarino, G. (2014). Participation, equality of opportunity and returns to tertiary education in contemporary Europe. European societies, 16(3), 422-442. https://doi.org/10.1080/1461 $\underline{6696.2012 .750729}$

Bonifazi, C. (2015). Le migrazioni tra Sud e Centro-Nord: persistenze e novità. In I. Gjergi (Ed.), La nuova emigrazione italiana. Cause, mete e figure sociali (pp. 57-69). Venezia, Edizioni Ca'Foscari.

Bonifazi, C., \& Heins, F. (2019). Di nuovo emigranti. Neodemos. Retrieved from http://www.neodemos. info/articoli/di-nuovo-emigranti

Bonifazi, C., Heins, F., \& Tucci, E. (2018). Internal migration in a low-mobility country. In: Champion, T., Shuttleworth, I., \& Cooke, T. (Eds.). Internal Migration in the Developed World: Are we becoming less mobile? (pp. 242-262). Routledge. https://doi.org/10.4324/9781315589282

Brynin, M. (2002). Overqualification in employment. Work, Employment and Society, 16(4), 667-654. https://doi.org/10.1177/095001702321587406

Budría, S., \& Moro-Egido, A. I. (2018). Qualification and skill mismatches: Europe in a cross-national perspective. Cuadernos Económicos de ICE, (95), 151-188. https://doi.org/10.32796/cice.2018.95.6646

Chabault, V. (2008). Sur-éducation et déclassement socioprofessionnel dans l'accès à l'emploi : état des lieux des publications nord-américaines et françaises. Revue des sciences de l'éducation, 34(1),185-202. https://doi.org/10.7202/018996ar

Delpirou, A., \& Rivière, D. (2013). Réseau urbain et métropolisation en Italie : héritages et dynamiques. Géoconfluences. Retrieved from http://geoconfluences.ens-lyon.fr/informations-scientifiques/dossiersthematiques/de-villes-en-metropoles/articles-scientifiques/reseau-urbain-et-metropolisation-enitalie-heritages-et-dynamiques

De Rosa, A., \& Strozza, S. (Ed.) (2015). L'Italia nella crisi economica. Rapporto sulla Popolazione. Associazione Italiana per gli Studi di Popolazione. Bologna: Il Mulino.

Di Paola, V. \& Moullet, S. (2012). Peut-on en finir avec le déclassement : Évolution du déclassement dans la fonction publique en début de carrière. Formation emploi, 2(2), 83-101. https://doi.org/10.4000/ formationemploi.3610

Doazan, Y., \& Eckert, H. (2014). Les jeunes et leurs diplômes. Le déclassement à l'aune de la valeur des titres scolaires. Éducation et sociétés, 34(2), 121-134. https://doi.org/10.3917/es.034.0121

Dubucs, H., Pfirsch, T., Recchi, E., \& Schmoll, C. (2017). Les migrations italiennes dans la France contemporaine. Hommes \& Migrations, 2017/2-3 (1317-1318), 55-59. https://doi.org/10.4000/ hommesmigrations.3871

Eckert, H. (2014). Déclassement et hantise du déclassement. Revue française de pédagogie, 188 (juilletaoût-septembre), 87-108. https://doi.org/10.4000/rfp.4552 
Eurostat (2019). Educational attainment statistics. Retrieved from https://ec.europa.eu/eurostat/statisticsexplained/index.php/Educational-attainment-statistics

Faggian, A., Rajbhandari, I., \& Dotzel, K. R. (2017). The interregional migration of human capital and its regional consequences: a review. Regional Studies, 51(1), 128-143. https://doi.org/10.1080/00343 $\underline{404.2016 .1263388}$

Forgeot, G., \& Gautié, J. (1997). Insertion professionnelle des jeunes et processus de déclassement. Économie et statistique, 304-305, 53-74. https://doi.org/10.3406/estat.1997.2556

Fullin, G., \& Reyneri, E. (2015). Una "via bassa" alla decrescita dell'occupazione: il mercato del lavoro italiano tra crisi e debolezze strutturali. Stato e mercato, (105), 469-508.

Gautié, J., \& Nauze-Fichet, E. (2000). Déclassement sur le marché du travail et retour au plein emploi. In J. Pisani-Ferry (Ed.), Plein Emploi, Rapport au Conseil d'analyse économique (pp. 277-288). Paris: La Documentation française.

Giret, J.-F., Nauze-Fichet, E., \& Tomasini, M. (2006). Le déclassement des jeunes sur le marché du travail. In Données sociales - La société française (pp. 307-314). Paris: Insee.

Giret, J.-F., Lopez, A., \& Rose, J. (Eds.) (2005). Des formations pour quels emplois. https://doi.org/10.3917/ dec.giret.2005.01

González-Leonardo, M., \& Gay, A. L. (2019). Emigración y fuga de talento en Castilla y León. Boletín de la Asociación de Geógrafos Españoles, 80 (2612), 1-31. https://doi.org/10.21138/bage.2612

González-Leonardo, M., Recaño, J., \& López-Gay, A. (2020). Selectividad migratoria y acumulación regional del capital humano cualificado en España. Investigaciones Regionales (47), 113-133. https:// doi.org/10.38191/iirr-jorr.20.013

Green, F., McIntosh, S., \& Vignoles, A. (2000). Sur-éducation: l'abus des bonnes choses ?. Formation emploi, 72, 49-57. https://doi.org/10.3406/forem.2000.2392

Hidalgo, Á., Calderón, M. J., \& Pérez, S. (2006). La discriminación salarial y segregación laboral de los inmigrantes: identificación de espacios laborales prioritarios para la intervención en materia de protección social. Ministerio de Trabajo y Asuntos Sociales. p.68.

Houdaille, J. (1970). Les migrations internes en Italie. Population, 25-5, 1089-1091. https://doi. org/10.2307/1530311

Iammarino, S., \& Marinelli, E. (2015). Education-Job (Mis)Match and Interregional Migration: Italian University Graduates' Transition to Work. Regional Studies, 49(5), 866-882. https://doi.org/10.1080/ $\underline{00343404.2014 .965135}$

Iammarino, S., \& Marinelli, E. (2017). Graduate over-education and spatial mobility in Italy. In J. Corcoran \& A. Faggian (Eds.), Graduate Migration and Regional Development (pp. 59-81). https://doi. org/10.4337/9781784712167.00008

Lemistre, P. (2009). Faut-il poursuivre l'expansion scolaire ?. Économie et statistique, 31, 1469-1501. Retrieved from https://halshs.archives-ouvertes.fr/halshs-00955341

Lemistre, P. (2014). Déclassement et chômage : une dégradation pour les diplômés ? État des lieux de 2007 à 2010. Net.Doc, 123. Retrieved from https://www.cereq.fr/declassement-et-chomage-unedegradation-pour-les-plus-diplomes

Merle, P. (2002). La démocratisation de l'enseignement. Paris: La Découverte.

McGuinness, S. (2006). Overeducation in the Labour Market. Journal of Economics Surveys, 20(3). https:// doi.org/10.1111/j.0950-0804.2006.00284.x

Maestripieri, L., \& Ranci, C. (2016). Non è un paese per laureati. La sovraqualificazione occupazionale dei lavoratori italiani. Stato e Mercato, 108, 425-450. https://doi.org/10.1425/85089

Meliciani, V., \& Radicchia, D. (2016). Informal networks, spatial mobility and overeducation in the Italian labour market. The Annals of Regional Science, 56, 513-535. https://doi.org/10.1007/s00168$\underline{016-0752-y}$

Moullet, S., Véro, J., \& Di Paola, V. (2005). Le déclassement dans les Fonctions publiques d'État et territoriale. In J.-F. Giret, A. Lopez \& J. Rose (Eds.), Des formations pour quels emplois (pp. 314-333). https://doi.org/10.3917/dec.giret.2005.01.0314 
Nauze-Fichet, E., \& Tomasini, M. (2002). Diplôme et insertion sur le marché du travail : approches socioprofessionnelle et salariale du déclassement. Économie et statistique, 354, 21-48. https://doi. org/10.3406/estat.2002.7383

Nauze-Fichet, E., \& Tomasini, M. (2005). Parcours des jeunes à la sortie du système éducatif et déclassement salarial. Économie et statistique, 388-389, 57-84. https://doi.org/10.3406/estat.2005.7170

Plassard, J.-M. (2015). La problématique de déclassement des diplômes et son impact sur les politiques de formation. Revue française de pédagogie, 192, juillet-août-septembre. https://doi.org/10.4000/rfp.4830

Pugliese, E. (2015). Le nuove migrazioni italiane: il contesto e i protagonisti. In I. Gjergi (Ed.), La nuova emigrazione italiana. Cause, mete e figure sociali (pp. 25-38). Venezia: Edizioni Ca'Foscari.

Salais, R. (1980). Le chômage comme un phénomène de file d'attente. Économie et statistique, 123, 67-78. https://doi.org/10.3406/estat.1980.4371

Svimez (2013). Rapporto Svimez 2013 sull'economica del Mezzogiorno. Bologna: Il Mulino.

Thurow, L. (1975). Generating Inequality. Mechanisms of Distribution in the U.S. Economy. New-York: Basic Books.

Van Puymbroeck, C. (2010). Répartition géographique des emplois. Les grandes villes concentrent les fonctions intellectuelles, de gestion et de décision. Insee Première, 1278. Retrieved from https://www. insee.fr/fr/statistiques/1281263

Verhaest, D., \& van der Velden, R. (2013). Cross-country differences in graduate overeducation. European Sociological Review, 29(3), 642-653. https://doi.org/10.1093/esr/jcs044 